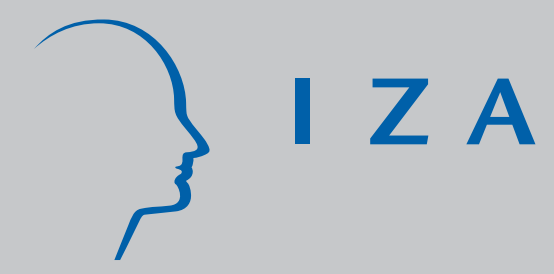

IZADP No. 2688

Real Wage Cyclicality in Germany and the UK: New Results Using Panel Data

Fei Peng

W. Stanley Siebert

March 2007 


\title{
Real Wage Cyclicality in Germany and the UK: New Results Using Panel Data
}

\author{
Fei Peng \\ University of Birmingham Business School \\ W. Stanley Siebert \\ University of Birmingham Business School \\ and IZA
}

Discussion Paper No. 2688

March 2007

IZA
P.O. Box 7240
53072 Bonn
Germany

Phone: +49-228-3894-0

Fax: +49-228-3894-180

E-mail: iza@iza.org

\begin{abstract}
Any opinions expressed here are those of the author(s) and not those of the institute. Research disseminated by IZA may include views on policy, but the institute itself takes no institutional policy positions.

The Institute for the Study of Labor (IZA) in Bonn is a local and virtual international research center and a place of communication between science, politics and business. IZA is an independent nonprofit company supported by Deutsche Post World Net. The center is associated with the University of Bonn and offers a stimulating research environment through its research networks, research support, and visitors and doctoral programs. IZA engages in (i) original and internationally competitive research in all fields of labor economics, (ii) development of policy concepts, and (iii) dissemination of research results and concepts to the interested public.
\end{abstract}

IZA Discussion Papers often represent preliminary work and are circulated to encourage discussion. Citation of such a paper should account for its provisional character. A revised version may be available directly from the author. 


\section{ABSTRACT \\ Real Wage Cyclicality in Germany and the UK: New Results Using Panel Data*}

This paper compares the cyclical behaviour of male real wages in Germany and the UK using the German Socio-Economic Panel 1984-2002 and the British Household Panel Survey 1991-2004. We distinguish between job stayers (remaining in the same job), and within- and between-company job movers. Stayers are the large majority in both countries. Using changes in the unemployment rate as the cyclical measure, we find real wages of stayers in the private sector in West Germany - but not East Germany - to be procyclical, and quite sensitive to unemployment, comparable to the US and the UK. We find cyclicality in the public sector in neither country. Thus real wage flexibility is similar in the two countries, apart from East Germany, despite apparent differences in wage-setting institutions.

JEL Classification: E32, J31, K31

Keywords: real wage cyclicality, job stayers, Germany, United Kingdom, GSOEP, BHPS

Corresponding author:

W. S. Siebert

Birmingham University Business School

University House

Edgbaston

Birmingham B15 2TT

United Kingdom

E-mail: w.s.siebert@bham.ac.uk

\footnotetext{
* The German Socio-Economic Panel Data (GSOEP) is used with the permission of the Department of Policy Analysis and Management at Cornell University, which has prepared an English User Version of the Public Use Sample and the Cross National Equivalent Files (CNEF) of the GSOEP. The British Household Panel Survey (BHPS) data used in this paper were made available through the UK Data Archive. The data were originally collected by the ESRC Longitudinal Studies Centre (ULSC), together with the Institute for Social and Economic Research (ISER) at the University of Essex. Neither the original collectors of the data or distributors bear any responsibility for the analyses or interpretations presented here. All remaining errors are our own.
} 


\section{REAL WAGE CYCLICALITY IN GERMANY AND THE UK: NEW RESULTS USING PANEL DATA}

\section{Introduction}

This paper analyses real wage adjustment over the business cycle using panel micro data for Germany 1984-2002 and the British Household Panel Survey 1991-2004. We follow here our companion paper which analyses real wage adjustment in Italy (Peng and Siebert, 2006). Germany, like Italy, has a regulated economy which forms an instructive contrast with the more flexible economies of the US and the UK, which have been shown to have significant real wage flexibility, using micro panel data (see Devereux 2001 for the US; and Devereux and Hart 2006 for the UK). Our aim is to provide a factual basis for inquiry, using microeconomic panel data from the German Socio-Economic Panel (GSOEP). We will apply the same variable definitions and analytical methods to the UK's British Household Panel Survey (BHPS), thus allowing a close comparison between Germany and the UK. Our study will have the further interest, for the UK economy, of providing results from the BHPS which can be compared to Devereux and Hart's (2006) analysis using the New Earnings Survey.

In practice, it is difficult unambiguously to classify a country's wage-setting institutions. Most discussions accept that collective agreements in the UK and the US are only important in certain sectors, and are neither centralised and/or coordinated. But Germany is more difficult. Franz and Pfeiffer (2006, Table 3) find that $57 \%$ of (private sector) employers they questioned believed labour union contracts were very important in preventing wage cuts for unskilled workers. However, this figure leaves a substantial minority, and the more skilled workers, for whom union contracts are not important. At the same time, Germany's system of pattern bargaining can be taken as highly coordinated (see e.g., Kenworthy, 2001, Figure 1), and also "governable" in Traxler's (2003) terms due to the legal enforceability of collective agreements. Ochel $(2005,105)$ argues that pattern bargaining, with wage agreements following the metalworking industry located in prosperous regions, may result in wages which are "excessive" for the economically weaker regions. On the other hand, he notes the possibility that Germany's coordinated wage setting results in wages being more responsive to macroeconomic shocks, since coordination assists in aligning the bargaining parties' expectations. In other words, the parties' gains to changing wages are higher if all change, so that there is a "strategic complementarity" (Ball and Romer, 1991) in wage adjustments. In this paper we directly test whether such coordination makes real wages responsive to macroeconomic shocks, making a crucial distinction between West and East Germany.

Our methodology which relies on panel data for individuals allows fine distinctions to be made between country regions, between public and private sector, and by firm size. It is worth testing all of these distinctions, which have implications for the way institutions affect wage flexibility. Thus, lower real wage procylicality among large firms - which are more affected by collective bargaining - would suggest this factor causes stickiness. Similarly, lower procyclicality in the public than the private sector would point to the extra authority of the state in setting public sector wages (Traxler, 1999), as well as softer public sector budget constraints. The alternative approach is to use aggregate country data, which is the method followed by current studies from the international wage flexibility project (Dickens et al, 2006; also Holden and Wulfsberg, 2007). This approach suggests widespread real wage rigidity since wage changes clump near expected inflation rates. Downward nominal wage rigidity also appears common. 
However, the aggregate method cannot test for differences within countries, which is our contribution.

A further advantage of our methodology is that we can follow Devereux and Hart's (2006) distinction between job stayers (remaining in the same job over the year), internal movers (i.e., within-company movers), and external movers (between-company). While job stayers are the most important numerically, bumping workers within the company up and down a job ladder (Reder's (1955) theory of internal job ladders) can provide a valuable further form of flexibility even if wages for stayers are rigid. Furthermore, as regards external movers, if this group experiences large real wage changes with the cycle, the implication is that incumbents are receiving rents. Again, such a finding might provide an insight into the working of labour market institutions in the particular case.

The remainder of this paper is organised as follows. In section II, we present our estimation methods, and in Section III, we describe the data. Section IV examines the basic predictions of theoretical models by region and compares our results with other findings. In Section IV, we also test the robustness of our results by company size and public-private sector. The final section concludes.

\section{Estimation methods}

Our empirical work uses the-standard two-step estimation procedure (beginning with Solon, 1994). The two-step procedure is designed to get round the Moulton (1986) problem that, though we have thousands of individuals, each year provides only one business cycle (unemployment) observation. Moulton (1986) shows that individuals in the same year will share some common component of variance that is not entirely attributable either to their measured characteristics (e.g., gender and age) or to the aggregate unemployment rate in that year. In this case, the error component in simple OLS regression will be positively correlated across people in the same year, so we will underestimate the standard error on the unemployment variable.

To circumvent this problem, in step 1 we estimate a wage change equation using individual data. This equation is given by:

$$
\Delta \ln w_{i t}=\alpha_{0}+\alpha_{1} \text { Age }_{i t}+\sum_{t=1}^{T} s_{t} Y_{t}+\sum_{t=1}^{T} w_{t} M_{\text {Wit }} Y_{t}+\sum_{t=1}^{T} b_{t} M_{B i t} Y_{t}+\varepsilon_{i t}
$$

where $\mathrm{w}_{\mathrm{it}}$ is the real hourly wage rate, Age $_{\mathrm{it}}$ is a cubic in age, $\mathrm{Y}_{\mathrm{t}}$ denotes a year dummy, and $\varepsilon_{i t}$ is a random error term. $\mathrm{M}_{\text {Wit }}$ denotes a dummy variable for internal movers, and $\mathbf{M}_{\mathrm{Bit}}$ is a dummy variable for external movers. This step gives us a time series of wage changes for the stayers, $\mathrm{s}_{\mathrm{t}}$; for the within-company movers, $\mathrm{w}_{\mathrm{t}}$; and for the betweencompany movers, $b_{t}$.

In step 2, we then derive estimates of the wage cyclicality of stayers, for example, by regressing $\mathrm{s}_{\mathrm{t}}$ on the unemployment change variable (we lag this one year, using $\Delta \mathrm{u}_{\mathrm{t}-1}$ ), and a linear time trend. In this step, we only have time series variation, reducing the number of observations - in our case 19 years for West Germany (1984-2002), 11 years for the East Germany (1992-2002) and 13 years for the UK (1991/2-2003/4). Again, this problem is standard (for example, Shin, 1994, has 12 time series observations), and the solution adopted, which we follow, is to use weighted least squares where the weights are 
the numbers of individuals observed in a given year. Our data cover more than one full business cycle in Germany and the UK. This equation is given by:

$$
\hat{s}_{t}=\delta_{0}+\delta_{1} \Delta u_{t-1}+\delta_{2} \text { Year }_{t}+v_{t}
$$

Equation (2) links to the decomposition of wage cyclicality given in the Appendix. Alternatively, using $\hat{w}_{t}$ in equation (2), the coefficient on $\Delta \mathrm{u}_{\mathrm{t}-1}$ gives the incremental wage response of within-company movers relative to stayers. Similarly, by using $\hat{b}_{t}$ as the dependent variable we can derive the incremental wage response of betweencompany movers relative to stayers.

Specification of the variables in equations (1) and (2) requires care in several respects, which we will cover in turn. First, there is the definition of the wage variable. Here we take quite a broad definition ${ }^{1}$, including overtime, bonuses, and profit-sharing (and also pay from second jobs in the case of the GSOEP) because this definition allows the best comparison between the GSOEP and the BHPS. This wage measure is close to the measures used in Solon et al (1994) and Devereux (2001) for the United States, and Peng and Siebert (2006) for Italy. Use of the broad definition will reduce the measured extent of rigidity: basic wages could be rigid while there could be flexibility in other components, especially bonuses and overtime. Thus, our results may show higher flexibility than results using the basic wage such as Devereux and Hart (2006) for the UK (see below). Still, flexibility imparted by variation in overtime and bonuses is genuine flexibility and should be considered.

A further issue is the definition of the wage deflator. Both the GSOEP and the BHPS provide data on consumer prices. We find it appropriate to deflate wages in Germany (West or East) by price indices for the appropriate region. In the case of the UK, we use a single price index.

Next, there is the definition of the hours variable. Since we work with annual earnings for Germany, we require a measure of annual hours. Annual hours worked is calculated by adding together the estimated annual hours of full-time, part-time, and short-time work. ${ }^{2}$ For the UK, the hourly wage is computed as the latest gross pay divided by the number of hours in the pay period. The working hours of the last pay period is the product of the number of weeks in the last pay period times weekly working hours including normal and overtime.

Errors in reporting of hours can give rise to spurious cyclicality of wages. In particular, workers may report contract hours rather than actual hours worked, causing reported hours to remain overly steady from year to year. Such understatement of the cyclicality of hours will give an overstatement of the cyclicality of hourly wages. We have checked our hours variable carefully. We find, even with 10 percent tolerance of the change in hours, on average, only $65 \%$ of job stayers had the same reported weekly hours in two adjacent years in the Germany. Tests on the BHPS also show many changes yearon-year in working hours. Only about $77 \%$ of job stayers have the same reported normal weekly hours in adjacent year. Thus, there seems to be significant variation in reported

\footnotetext{
${ }^{1}$ We exclude the self-employed, because of difficulties with the reliability of their self-reported pay figures.

${ }^{2}$ Annual hours of work in each of these three states is calculated by multiplying the average number of hours worked per week by the number of months worked in each of these three states for the previous year and by 4.33 (the average number of weeks per month).
} 
hours from year to year in both Germany and the UK, especially given that true hours are likely to remain constant for most stayers. Furthermore, hours show some significant procyclicality in a regression with the unemployment rate, which is reasonable. Thus, we take it that the bias from misreporting of hours is not large for our data.

Next, there is the issue of whether to use a regionally differentiated unemployment variable, or a country-wide variable. If labour mobility between regions is low, then regional differentiation is indicated. We experimented with both types, including a South versus North-Central split for the UK, as well as the obvious East-West split for Germany. We found that regional differentiation for Germany gave the most sensible results, together with a single unemployment variable for the UK, and accordingly report this specification.

There is also the question of forming the stayer and the within- and betweencompany mover groups. For both datasets, we use tenure with the company: if the tenure is one year or less, the respondent is a between-company mover, otherwise, a job stayer or within-company mover. (We remove new entrants to the labour market from the category of external movers.). We identify a job stayer as an employee who answers yes to the direct question “Are you working in your original job?" in the case of the GSOEP, and a similar question for the BHPS ${ }^{3}$. If there is a missing value for this question, we identify a stayer as an individual who has no change in residential area, working sector and industry. A within-company mover is then a worker whose tenure is more than one year but is not a job stayer. ${ }^{4}$

Finally, there is the question of what to do about structural breaks over time. For East Germany, we drop the 1991 observation, so as to avoid the special wage turbulence associated with re-unification. For West Germany, there is the possibility that over the long time period we consider, the underlying bargaining structure changes, particularly since the late 1990s (see Doellgast and Greer, 2007). In fact, our sample period for Germany ends in 2002, and hence will not be much affected by such recent changes.

\section{Data Description}

The GSOEP is a wide-ranging representative longitudinal study of private households in Germany. The same private households, persons and families have been surveyed yearly since 1984 (the GSOEP West). In June 1990, the survey was extended to the territory of the former German Democratic Republic (the GSOEP East). In 1984, 5,624 households containing a total of 15,729 individual respondents participated in the GSOEP West. After the joining of the GSOEP East in 1990, an immigrant sample was added as well to account for the changes that took place in Germany society in 1994/95. Further new samples were added in 1998, 2000 and 2002. Thus, with a high degree of stability over

\footnotetext{
${ }^{3}$ The BHPS asks a direct question: "What was the date you started working in your present position, by that I mean the beginning of your current spell of the job you are doing now for your present employer?" which provides clear information about the starting year of the job spell.

${ }^{4}$ The GSOEP provides good data on 17 residential areas, public/private sector and one digit (9) and two digit (33) industries of current jobs. We choose one digit industries to define the job stayer here, because using two digit industries affects little. When we limit the sample only to those defined as job stayers from the direct question, our basic conclusions do not change. For the BHPS, we use 19 residential areas, public/private sector and four digit (9999) industries of current job to define job stayers. However, the BHPS updated the industry categorisation from the SIC80 to the SIC92 in the 2002/2003 survey. Thus, only in that year, we use one digit (5) industries. Our results for the UK are not sensitive to the choice of industry variables rather than the direct question.
} 
time, there were 12,055 households containing a total 29,982 individual respondents participating in 2002.

For this research, we formed an unbalanced panel of 20,574 male workers with clear employment information, in which 16,474 workers are from West Germany for the period 1984-2002 and 4,100 from East Germany for the period 1992-2002 (see Table 1). In concentrating on males, we are following the literature (e.g., Devereux, 2001; Shin and Solon, 2006). In any case, the female participation rate in Germany is only about 65 percent, compared with about 80 percent for the males, so that our female sample would be much less than males, giving difficulties when we analyse sub-groups.

For the United Kingdom, we use the first thirteen waves of the BHPS, which was designed as an annual survey of each adult (16+) member of a nationally representative sample of more than 5,000 households in the UK, making a total of approximately 10,000 individual interviews yearly. The same individuals are re-interviewed in successive waves. A development in 1999/2000 was the recruitment of two additional samples from Scotland and Wales to increase the relatively small sample sizes for these regions. In 2001/2002, an additional sample from Northern Ireland was added. Thus, the sample should remain broadly representative of the whole population of the UK as it changed through the 1990s and beyond. From this dataset, we formed an unbalanced panel of 13,758 male workers with clear employment information.

Table 1 presents summary statistics for (the former) West and East Germany and the UK, for the key variables. The three columns seem quite similar in the first and second panels, apart from the fact that the workplaces are much smaller in the UK (68\% small/medium companies) and East Germany (66.3\%) than West Germany (only 47\%). ${ }^{6}$ There is a somewhat higher proportion working in private sector in the West Germany, but few temps and part timers in either country, as is to be expected in an all-male sample. It seems that the proportion of job stayers is a little higher in the West Germany, while the external movers' proportion is a little higher in the East. The internal movers' proportion is distinctly lower in the UK than Germany, either west or east. Perhaps the bigger firm size of German companies provides more space and resources for internal promotion/demotion than in the UK.

\section{(Table 1 around here)}

As regards wage levels, we see that wages in the West are much higher than in the East. There is an overall wage gap of approximately 40 percent between the East and West. Also, for both German regions (and for the UK), public sector wages are equivalent to wages of large companies in the private sector, which are about 20 percent higher than small/medium companies in the private sector.

In Germany, centralised collective agreements have been used to push East German wages up from 7\% of West German levels at the time of unification in 1989, to

\footnotetext{
${ }^{5}$ Though the GSOEP East actually started in 1990, there is no employment information for workers in 1990 and 1991. Thus, our data for the East Germany is actually for the period of 1992-2002.

${ }^{6}$ The GSOEP and the BHPS can only provide categorized information by employer size. We define a small company as a workplace with less than 20 (25) employees, a medium company as one with from 20 (25) to 200 employees, and a big company as one with 200 to 2000 (1000) employees. A large company has 2000 (1000) or more employees in Germany (the UK).
} 
about $72 \%$ in 2002 (Ochel 2005). As Ochel (2005, 167) argues, the initial collective wage negotiations in Germany were "proxy negotiations" that were carried out by West Germany employers' associations and trade unions with the aim of equalisation of wages across Germany. High welfare payments subsequently have permitted the high wages to continue. This uplifting of wages in the East seems to have had the same speed in the public and large-firm private sectors, but been somewhat slower in the small firm category (a 40\% gap can be detected here between East and West).

Evidence on the uplifting of East German wages is also shown in the wage change data at the bottom of the table, where we see that job stayers and internal movers in the East Germany have faster wage growth than those in the West. However, external movers do not. In fact, external movers in both East and West Germany suffer negative wage changes on average - in contrast to the UK - pointing to involuntary moves, and rents for incumbents ${ }^{7}$.

\section{Empirical results}

The GSOEP results for the unemployment change coefficients from equation (2) are reported in Table 2, for the East and West separately. We differentiate between the public sector and the private sector. Also, within the private sector we consider different size company categories to test whether the opt-out from collective agreements (Ochel, 2005, 95) permitted to small firms makes their wage movements any more procyclical.

Furthermore, small companies (under 5 or 10 employees in the legislation) are less likely to be covered by employment protection laws (Ebbinghaus and Eichhorst 2006, p19), meaning less shielding of job stayers and accordingly more wage flexibility

\section{(Table 2 near here)}

The table shows markedly different labour markets in the West and East. Real wages of job stayers in the private sector in the West, regardless of the firm size, exhibit significant and highly procyclical movements. However, private sector wages in the East are rigid except for large firms with more than 2000 employees. It appears as though the pattern bargaining in the West delivers wage flexibility in that area's private sector, but not in the East. Interestingly, there is no evidence of greater flexibility among small firms in the West, which suggests that there is not so much benefit to being "untrammelled" by collective agreements. Put in another way, for the big firms which lead the collective bargaining, the benefits of coordination are real. However, these benefits do not extend to the East, where wages set are above equilibrium except for the very large firms (2000+). Public sector wage behaviour is more similar in the two regions, being completely inflexible.

The results for the BHPS are presented in Table 3. The top panel gives results for the country as a whole, while the bottom reports on the South-North split. Taking the whole country first, we see that the pattern of real wage cyclicality is similar to that in the West Germany, with the private sector flexible, and the public sector not. (Here we differ from Devereux and Hart (2006) who find significant, though lower, flexibility for the UK public sector based on New Earnings Survey data.) It is also worth noting how in the public sector the incremental wage effect for external movers is high and significant (-

\footnotetext{
${ }^{7}$ Our wage change statistics for the UK are similar to those in Devereux and Hart (2006), in particular the large positive wage changes for between-company movers.
} 
3.94). This result implies that moving into and out of public sector over the cycle has strong wage consequences, as would be expected if rents were available to incumbent workers in the sector.

\section{(Table 3 around here)}

In the bottom panel we give some results from experiments with dividing the UK into two regions: the South, and the North, using corresponding regional unemployment rates. Here we pool the public and private sectors for simplicity. As can be seen, there is not much difference in the estimates for the two regions, in both of which stayers' real wages are significantly procyclical. The chi-square test for equality of coefficients is easily passed. Thus, there in no extra wage inflexibility in the UK's North, such as might occur if wage-setting mechanisms imposed wage movements derived from the prosperous South. The picture of regional labour segmentation in Germany, and Italy (see Feng and Siebert, 2006) is quite different.

Comparing Tables 2 and 3 we see that wage flexibility in the private sector of the UK appears to be similar to that in West Germany. Further, it must be remembered that we are using a similar wage definition for both datasets, and are comparing like with like. The finding UK (private sector) wage flexibility is just as great as - if not greater than West German, is a point against the view that coordination of bargaining is necessary for firms in an industry to be willing to alter their wages. In fact, there has not been much coordination of private sector bargaining in the UK for some time. For example, the famous engineering agreement came to an end in 1989, when the Engineering Employers withdrew from national bargaining.

Making comparisons with other research using panel data, our findings in Tables 2 and 3 indicate that real wage cyclicality - for West Germany at least - is comparable with that in the US and UK. Thus, for male stayers in the US, Solon et al (1994) find an elasticity of -1.2 for male stayers, and Shin and Solon (2006) find a similar -1.5 . Also for the US, Devereux (2001) finds -1.09 for male job stayers (using a narrow wage definition). For the UK, Devereux and Hart (2006) find -1.93 for male private sector stayers, which is a little lower than our findings for the BHPS, perhaps due to their using a more narrowly defined wage variable. For Italy, Peng and Siebert (2006) find considerable wage cyclicality for private sector male stayers in the Northern Italy (-3.6) but inflexibility in the Centre-South region. Thus, the problem of inflexible real wages affects specifically lagging regions such as East Germany and Southern Italy, and of course the public sector everywhere.

\section{Conclusions}

This paper compares the cyclical behaviour of male real wages in Germany and the UK using the GSOEP 1984-2002 and the BHPS 1991-2004. Following the methodology in particular of Devereux and Hart (2006) we distinguish between job stayers (remaining in the same job), and within- and between-company job movers. Stayers are the large majority in both countries. Using changes in the unemployment rate as the cyclical measure, we find real wages of stayers in the private sector in West Germany - but not East Germany - to be procyclical, and quite sensitive to unemployment, comparable to the US and the UK. We find cyclicality in the public sector in neither country. Furthermore, for the UK we find that real wages in the North are just as procyclical as in the-South. There is nothing like the marked and continuing regional labour market 
segmentation that is to be found between West and East Germany, or North and South Italy.

The results suggest that real wages are not sticky in the private sectors both of the UK and West Germany. It is in the public sector of both countries, and in East Germany, that stickiness occurs. However, we might argue that both these cases of sticky wages are special. For the public sector case, there might be little reason to expect labour demand movements to be in step with the aggregate unemployment rate, and for East German case there is the unique shock of unification. We are then left with a comparison of the private sectors of the UK and West Germany, both of which appear to be similarly flexible, whatever the underlying differences in wage-setting institutions - be it the pattern bargaining coordination of West Germany, or the company bargaining and individualism of the UK. The policy conclusion seems to be that when regions within a country are reasonably prosperous, the two types of wage-setting institution give the same result. However, when a region is lagging, as in the case of East Germany or Italy's South, pattern bargaining delays recovery. 
Table 1: Means and Standard Deviations, Males in the GSOEP and the BHPS

(Standard deviations in parentheses)

\begin{tabular}{|c|c|c|c|c|c|}
\hline & \multicolumn{2}{|c|}{ Variable } & $\begin{array}{l}\text { West } \\
\text { Germany } \\
(1984- \\
\text { 2002) }\end{array}$ & $\begin{array}{l}\text { East } \\
\text { Germany } \\
(1992- \\
\text { 2002) }\end{array}$ & $\begin{array}{l}\text { UK } \\
(1991- \\
2004)\end{array}$ \\
\hline \multirow{4}{*}{$\begin{array}{l}\text { Proportions of } \\
\text { total } \\
\text { observations: }\end{array}$} & \multicolumn{2}{|c|}{ Private sector } & 0.805 & 0.772 & 0.783 \\
\hline & \multicolumn{2}{|c|}{ Permanent contracts* } & 0.933 & 0.903 & 0.925 \\
\hline & \multicolumn{2}{|c|}{$\begin{array}{l}\text { Workers in small } \\
\text { /medium company } \\
\text { (employees<200) }\end{array}$} & 0.470 & 0.663 & 0.680 \\
\hline & \multicolumn{2}{|c|}{ Full-time workers } & 0.872 & 0.872 & 0.921 \\
\hline \multirow{3}{*}{$\begin{array}{l}\text { Worker } \\
\text { movement: } \\
\text { proportions of } \\
\text { total } \\
\text { observations: }\end{array}$} & \multicolumn{2}{|c|}{ Job stayers } & 0.831 & 0.785 & 0.793 \\
\hline & \multicolumn{2}{|c|}{ Internal movers } & 0.150 & 0.141 & 0.078 \\
\hline & \multicolumn{2}{|c|}{ External movers } & 0.114 & 0.156 & 0.129 \\
\hline \multirow{3}{*}{$\begin{array}{l}\text { Mean real } \\
\text { wage, } 1995 \\
\text { prices } \\
(\operatorname{lnW})^{* *}:\end{array}$} & \multicolumn{2}{|l|}{ Overall } & $\begin{array}{c}3.22 \\
(0.45)\end{array}$ & $\begin{array}{c}2.82 \\
(0.44)\end{array}$ & $\begin{array}{c}1.93 \\
(0.49)\end{array}$ \\
\hline & \multicolumn{2}{|c|}{ Public sector } & $\begin{array}{c}3.31 \\
(0.38)\end{array}$ & $\begin{array}{c}2.97 \\
(0.36)\end{array}$ & $\begin{array}{c}2.08 \\
(0.44)\end{array}$ \\
\hline & $\begin{array}{l}\text { Private } \\
\text { sector: }\end{array}$ & $\begin{array}{l}\text { Big/large } \\
\text { company }(\geq 200) \\
\text { Small/medium } \\
\text { company }(<200)\end{array}$ & $\begin{array}{c}3.33 \\
(0.39) \\
3.11 \\
(0.47)\end{array}$ & $\begin{array}{c}2.99 \\
(0.38) \\
2.71 \\
(0.44)\end{array}$ & $\begin{array}{c}2.05 \\
(0.46) \\
1.82 \\
(0.49)\end{array}$ \\
\hline \multirow{3}{*}{$\begin{array}{l}\text { Real wage } \\
\text { changes } \\
(\Delta \ln W)^{* * *}:\end{array}$} & \multicolumn{2}{|c|}{ Job stayers $\left(\Delta \ln \mathrm{W}_{\mathrm{S}}\right)$} & $\begin{array}{l}0.011 \\
(0.25)\end{array}$ & $\begin{array}{l}0.017 \\
(0.26)\end{array}$ & $\begin{array}{l}0.026 \\
(0.39)\end{array}$ \\
\hline & \multicolumn{2}{|c|}{ Internal movers $\left(\Delta \ln \mathrm{W}_{\mathrm{W}}\right)$} & $\begin{array}{l}0.008 \\
(0.27)\end{array}$ & $\begin{array}{l}0.011 \\
(0.28)\end{array}$ & $\begin{array}{l}0.066 \\
(0.38)\end{array}$ \\
\hline & \multicolumn{2}{|c|}{ External movers $\left(\Delta \ln W_{B}\right)$} & $\begin{array}{l}-0.017 \\
(0.36)\end{array}$ & $\begin{array}{l}-0.026 \\
(0.34)\end{array}$ & $\begin{array}{l}0.067 \\
(0.52)\end{array}$ \\
\hline \multicolumn{3}{|c|}{ Number of individuals } & 16,474 & 4,100 & 13,758 \\
\hline \multirow{2}{*}{\multicolumn{3}{|c|}{$\begin{array}{l}\text { Average number of observations each year } \\
\text { Total number of observations }\end{array}$}} & 5,687 & 2,096 & 5,789 \\
\hline & & & 108,056 & 23,052 & 75,262 \\
\hline
\end{tabular}

Notes: * The consistent contract variables in the GSOEP only appear in 1985, 1988 and 1995-2002

** Log form wages are only for full-time workers.

*** Wage changes are only for full-time workers, excluding outlying cases. 
Table 2 Real wage and unemployment changes, by sector and firmsize, Males in the GSOEP (coefficients on $\Delta \mathrm{u}_{\mathrm{t}-1}$ from wage change equation 2)

\begin{tabular}{|c|c|c|c|c|c|c|c|}
\hline & & \multicolumn{3}{|c|}{ West (1984-2002) } & \multicolumn{3}{|c|}{ East (1992-2002) } \\
\hline & & \multirow{2}{*}{$\begin{array}{c}\text { Job } \\
\text { stayers }\end{array}$} & \multicolumn{2}{|c|}{ Incremental effects: } & \multirow{2}{*}{$\begin{array}{c}\text { Job } \\
\text { stayers }\end{array}$} & \multicolumn{2}{|c|}{ Incremental effects: } \\
\hline & & & internal movers & external movers & & internal movers & external movers \\
\hline \multicolumn{2}{|c|}{ Public Sector } & -0.54 & 1.42 & -2.66 & 0.50 & -0.30 & -1.93 \\
\hline \multirow{8}{*}{$\begin{array}{l}\text { Private } \\
\text { sector: }\end{array}$} & Small firm & 152* & 0,5 & 165 & ב? 0 & ב? & 010 \\
\hline & $(\sim 20)$ & $(091)$ & $(276)$ & $(262)$ & $(0.41)$ & $(228)$ & $(0.10$ \\
\hline & Medium firm & $-1.40 * * *$ & -0.90 & -2.97 & -0.30 & -0.06 & 1.41 \\
\hline & $(20 \sim 200)$ & $(0.43)$ & (2.61) & $(2.62)$ & $(0.36)$ & (0.99) & $(1.62)$ \\
\hline & Big firm & $-1.83^{* * *}$ & -0.92 & -0.69 & -0.76 & 0.61 & 2.31 \\
\hline & $(200 \sim 2000)$ & $(0.56)$ & (1.41) & (2.67) & $(0.61)$ & (1.44) & (2.07) \\
\hline & Large firm & $-0.97 * *$ & -1.35 & -6.94 & $-0.68 * *$ & 1.90 & -0.62 \\
\hline & $(2000 \sim)$ & $(0.44)$ & (1.97) & $(6.50)$ & $(0.34)$ & (1.99) & (3.41) \\
\hline
\end{tabular}

Notes: Standard errors are in parentheses. ***, ** and * denote significance at $1 \%, 5 \%$ and $10 \%$ levels for two-tail tests. There are 55,233 individual observations in the first stage (46,848 for the west and 8,385 for the east), and 17/10 region-wide weighted time-series observations for the west/east in the second stage. 
Table 3 Real wage and unemployment changes by sector and firm size, Males in the BHPS 1991-2004

(coefficients on $\Delta \mathrm{u}_{\mathrm{t}-1}$ from wage change equation 2)

\begin{tabular}{|c|c|c|c|c|}
\hline & \multicolumn{3}{|c|}{ Males (1991-2004) } \\
\hline & & $\begin{array}{c}\text { Job } \\
\text { stayers }\end{array}$ & $\begin{array}{l}\text { Incremental } \\
\text { effect for } \\
\text { internal movers }\end{array}$ & $\begin{array}{c}\text { Incremental } \\
\text { effect for } \\
\text { external movers }\end{array}$ \\
\hline \multicolumn{5}{|c|}{ Whole Economy } \\
\hline \multicolumn{2}{|c|}{ Public Sector } & $\begin{array}{c}0.03 \\
(0.81) \\
\end{array}$ & $\begin{array}{l}-1.47 \\
(3.44) \\
\end{array}$ & $\begin{array}{l}-3.94 * \\
(2.13) \\
\end{array}$ \\
\hline \multirow{4}{*}{$\begin{array}{l}\text { Private } \\
\text { sector: }\end{array}$} & $\begin{array}{l}\text { Small firm } \\
(\sim 25)\end{array}$ & $\begin{array}{l}-2.16^{* *} \\
(0.90)\end{array}$ & $\begin{array}{r}4.41 \\
(2.49)\end{array}$ & $\begin{array}{c}1.88 \\
(2.42)\end{array}$ \\
\hline & \multirow{2}{*}{$\begin{array}{l}\text { Medium firm } \\
(25 \sim 200) \\
\text { Big firm } \\
(200 \sim 1000)\end{array}$} & $\begin{array}{c}-1.26 * * \\
(0.65) \\
-3.12^{* * *}\end{array}$ & $\begin{array}{c}0.46 \\
(1.73) \\
-0.54\end{array}$ & $\begin{array}{c}0.20 \\
(1.14) \\
-0.90\end{array}$ \\
\hline & & $(0.61)$ & $(2.79)$ & (2.13) \\
\hline & \multirow[t]{2}{*}{$\begin{array}{l}\text { Large firm } \\
(1000 \sim)\end{array}$} & $\begin{array}{c}-2.69^{* *} \\
(1.26) \\
\end{array}$ & $\begin{array}{l}-0.83 \\
(2.91) \\
\end{array}$ & $\begin{array}{l}-1.35 \\
(4.51) \\
\end{array}$ \\
\hline \multicolumn{4}{|c|}{ North-South Split } & \\
\hline \multicolumn{2}{|l|}{ South } & $\begin{array}{c}-1.23^{* * *} \\
(0.48)\end{array}$ & $\begin{array}{c}0.48 \\
(1.96)\end{array}$ & $\begin{array}{l}-2.25 \\
(1.36)\end{array}$ \\
\hline \multicolumn{2}{|c|}{ North-Central } & $\begin{array}{c}-1.69 * * * \\
(0.50)\end{array}$ & $\begin{array}{c}0.90 \\
(0.69)\end{array}$ & $\begin{array}{c}0.19 \\
(1.12)\end{array}$ \\
\hline \multicolumn{4}{|c|}{$\begin{array}{l}\text { Chi-square test for equality of coefficients for South and North- } \\
\text { Central }\end{array}$} & $4.44(\mathrm{p}>0.618)$ \\
\hline
\end{tabular}

Notes: Standard errors are in parentheses. ${ }^{* * *}, * *$ and $*$ denote significance at $1 \%, 5 \%$ and $10 \%$ levels for two-tail tests. There are 25,667 individual observations in the first stage, and 12 region-wide weighted time-series observations for the second stage. 


\section{References}

Ball, L, and D Romer. (1991), "Sticky Prices as Coordination Failure”, American Economic Review, 81(3): 539-52.

Devereux, P. (2001). “The Cyclicality of Real Wages Within Employer-Employee Matches.” Industrial and Labor Relations Review, 54: 835-850.

Devereux, J. and R A. Hart. (2006). "Real Wage Cyclicality of Job Stayers, WithinCompany Job Movers, and Between-Company Job Movers.” Industrial and Labor Relations Review, 60: 105-119.

Doellgast V and I Greer (2007). "Vertical Disintegration and the Disorganization of German Industrial Relations”, British Journal of Industrial Relations, 45: 55-76.

Dickens, W, L Goette, S Holden, J Messina, M Schweitzer, J Turunen and M Ward (2006). "How wages Change: Micro Evidence from the International Wage Flexibility Project”, IZA Discussion Paper No. 2487.

Ebbinghaus, B and W Eichhorst. (2006). "Employment Regulation and Labor Market Policy in Germany, 1991-2005”. IZA Discussion Paper No. 2405

Franz, W and F Pfeiffer. (2006). “Reasons for Wage Rigidity in Germany”. Labour, 20 (2), pp. 255-284.

Holden, Steinar and Fredrik Wulfsberg. (2007). "Downward nominal wage rigidity in the OECD”, University of Oslo Working Paper. http://www.oekonomi.uio.no/ansatte/sholden.xml

Kenworthy, L. (2001). "Wage-setting Measures: A Survey and Assessment”. World Politics, 54: 57-98

Moulton, B R. (1986). "Random Group Effects and the Precision of Regression Estimates.” Journal of Econometrics, 32: 385-397.

Ochel, W. (2005). "Decentralizing Wage Bargaining in Germany - A Way to Increase Employment?” Labour, 19 (1): 91-121.

Peng, F and W S Siebert (2006). "Real Wage Cyclicality in Italy”, IZA Discussion Paper No.2465.

Reder, M W. (1995). “The Theory of Occupational Wage Differentials.” American Economic Review, 45: 833-52.

Shin, D. (1994). “Cyclicality of Real Wages Among Young Men.” Economics Letters, 46: 137-142.

Shin, D and Solon, G. (2006). "New Evidence On Real Wage Cyclicality Within Employer- Employee Matches.” NBER Working Paper No.12262.

Solon, G, R. Barsky, and J A Parker. (1994). "Measuring the Cyclicality of Real Wages: How Important Is Composition Bias?” Quarterly Journal of Economics, 109: 126.

Solon, G, W Whatley, and A Stevens. (1997). "Wage Changes and Intracompany Job Mobility over the Business Cycle: Two Case Studies.” Industrial and Labor Relations Review, 50: 402-415.

Traxler (1999). "The State in Industrial Relations: a Cross-National Analysis of Developments aand Socio-Economic Effects”, European Journal of Political Research, 36: 55-85.

Traxler (2003). "Bargaining (De)centralization, Macroeconomic Performance and Control over the Employment Relationship”, British Journal of Industrial Relations, 41: 1-27. 


\section{Appendix \\ Estimation Methodology}

The standard decomposition of wage growth (Solon et al, 1997, and Devereux and Hart, 2006), distinguishing between jobstayers and internal and external movers is:

$$
\begin{aligned}
\mathrm{E}(\Delta \ln \mathrm{W}) & =\left(1-\mathrm{P}_{\mathrm{W}}-\mathrm{P}_{\mathrm{B}}\right) \mathrm{E}\left(\Delta \ln \mathrm{W}_{\mathrm{S}}\right)+\mathrm{P}_{\mathrm{W}} \mathrm{E}\left(\Delta \ln \mathrm{W}_{\mathrm{W}}\right)+\mathrm{P}_{\mathrm{B}} \mathrm{E}\left(\Delta \ln \mathrm{W}_{\mathrm{B}}\right) \\
& =\mathrm{E}\left(\Delta \ln \mathrm{W}_{\mathrm{S}}\right)+\mathrm{P}_{\mathrm{W}} \mathrm{E}\left(\Delta \ln \mathrm{W}_{\mathrm{W}}-\Delta \ln \mathrm{W}_{\mathrm{S}}\right)+\mathrm{P}_{\mathrm{B}} \mathrm{E}\left(\Delta \ln \mathrm{W}_{\mathrm{B}}-\Delta \ln \mathrm{W}_{\mathrm{S}}\right)
\end{aligned}
$$

where $\mathrm{P}_{\mathrm{W}}$ and $\mathrm{P}_{\mathrm{B}}$ denotes the proportion of workers changing jobs within and between companies, and $\mathrm{E}\left(\Delta \ln \mathrm{W}_{\mathrm{S}}\right), \mathrm{E}\left(\Delta \ln \mathrm{W}_{\mathrm{W}}\right)$, and $\mathrm{E}\left(\Delta \ln \mathrm{W}_{\mathrm{B}}\right)$ is the expected wage growth of job stayers (S), internal movers (W) and external movers (B).

Differentiating equation (1) with respect to the change in the unemployment rate, $\Delta \mathrm{u}$, provides a decomposition of total wage cyclicality:

$$
\begin{aligned}
\partial \mathrm{E}(\Delta \ln \mathrm{W}) / \partial(\Delta \mathrm{u}) & =\partial \mathrm{E}\left(\Delta \ln \mathrm{W}_{\mathrm{S}}\right) / \partial(\Delta \mathrm{u}) \\
& +\mathrm{P}_{\mathrm{W}}\left[\partial \mathrm{E}\left(\Delta \ln \mathrm{W}_{\mathrm{W}}-\Delta \ln \mathrm{W}_{\mathrm{S}}\right) / \partial(\Delta \mathrm{u})\right] \\
& +\mathrm{P}_{\mathrm{B}}\left[\partial \mathrm{E}\left(\Delta \ln \mathrm{W}_{\mathrm{B}}-\Delta \ln \mathrm{W}_{\mathrm{S}}\right) / \partial(\Delta \mathrm{u})\right] \\
& +\partial \mathrm{P}_{\mathrm{W}} / \partial(\Delta \mathrm{u})\left[\mathrm{E}\left(\Delta \ln \mathrm{W}_{\mathrm{W}}-\Delta \ln \mathrm{W}_{\mathrm{S}}\right)\right] \\
& +\partial \mathrm{P}_{\mathrm{B}} / \partial(\Delta \mathrm{u})\left[\mathrm{E}\left(\Delta \ln \mathrm{W}_{\mathrm{B}}-\Delta \ln \mathrm{W}_{\mathrm{S}}\right)\right]
\end{aligned}
$$

The first term is the wage response of job stayers; the second term defines the incremental effect of wage cyclicality on internal movers relative to stayers, and the third term defines the incremental effect of wage cyclicality on external movers relative to stayers. The last two terms represent the cyclicality of the probability of internal and external job changes. Since these terms are small, we concentrate on the wage responses. 